UDC 616.5:616-089.843

\title{
Different types of biotechnological wound coverages created with the application of alive human cells
}

\author{
A. Ye. Papuga, L. L. Lukash \\ Institute of Molecular Biology and Genetics, NAS of Ukraine \\ 150, Akademika Zabolotnoho Str., Kyiv, Ukraine, 03680 \\ alexander.papuga@gmail.com
}

\begin{abstract}
Currently, the development and the implementation of the new biotechnological wound coverings (skin equivalents) designed for temporal or permanent replacement of damaged or destroyed areas of human skin remains extremely actual relevant in clinical practice. Skin equivalents or equivalents of individual skin layers which include alive cells of different types take a special place among the artificial wound coverings. They mostly contain two basic types of cells - fibroblasts and keratinocytes (together or separately). Such bioconstructions are usually served as temporary coverings, which supply the damaged skin by biologically active substances and stimulate the regeneration of the patient's own tissues. In this review we consider as commercially available wound coverings and those which are still studied in the laboratories. Until now ideal substitutes of natural skin have not yet created, so the efforts of many researchers are focusing on the solution of this problem.
\end{abstract}

Keyw ord s: artificial skin, skin equivalents or substitutes, wound dermal coverages, tissue engineering, cell, wound.

\section{Introduction}

Autodermoplastics is traditionally used to cover vast wounds. However, this method does not allow covering the whole surface of the wound even with mesh autodermotransplantat, if the total area of the wound exceeds $30-40 \%$ of the body area. One of the ways to solve this problem is the application of biotechnological wound coverages, which may be divided into two kinds: non-cell ones and those, containing living cells of different types and origin. There are currently no ideal bioconstructions, which would meet all the criteria, thus the research is still under way.

Let us consider the requirements to the ideal biological skin equivalent:

- no antigenicity; skin compatibility,

- no local or systemic toxicity,

- no permeability for exogenous microorganisms,
- inhibition of the activity of microorganisms in the wound,

- moisture permeability, similar to that of normal skin,

- sufficient adhesion to the wound surface,

- compliance with the surface irregularities,

- elasticity, not disturbing the mobility of subiculums,

- resistance to linear and shifting deformations,

- longitudinal strength,

- biodegradation ability,

- extensive lifetime and simplicity of storing,

- low cost,

- usability for medical staff,

- acceptability and minimal discomfort for a patient,

- semitransparency to have the possibility of observing the process of wound healing,

(C) 2015 A. Ye. Papuga, L. L. Lukash; Published by the Institute of Molecular Biology and Genetics, NAS of Ukraine on behalf of Biopolymers and Cell. This is an Open Access article distributed under the terms of the Creative Commons Attribution License (http://creativecommons.org/licenses/by/4.0/), which permits unrestricted reuse, distribution, and reproduction in any medium, provided the original work is properly cited 
- shortened time of wound healing [1].

Experimental data prove the relevance of the contact of wound surface and different types of cells, which may be a part of artificial skin substitutes. At present there are two main types of cells, which are the components of clinically available bioconstructions, - keratinocytes and fibroblasts (together or separately). The processes of proliferation and differentiation of keratinocytes are known to have better performance in the presence of fibroblasts; in turn, the functional state of fibroblasts depends on the effect of keratinocytes [2]. For instance, it was demonstrated that biologically active substances, discharged by fibroblasts, affect the proliferation and migration of skin melanocytes [3]. At the same time all the clinically applied skin equivalents do not contain any nervous or immune cells, sweat glands and hair follicles, therefore, they are not capable of performing all the skin functions. As a rule, these bioconstructions act as temporary biologically active wound coverages, providing the damaged tissues with the components of extracellular matrix, cytokines and growth factors (vitronectin, tenastin, collagen, glycosaminoglycans, interleukins $1,6,8$, interferons $\alpha$ and $\beta$, PDGF, FGF-1, KGF-1, PDGF, VEGF (vascular endothelial growth factor), TGF- $\alpha$ ) [4, 5]. Due to this fact there is the migration of the recipient organism cells into the wound area along with their proliferation, regeneration of the dermal layer and wound re-epithelization, the wound area is «condi- tioned» for the use of skin transplantats. It promotes shortening the period of wound healing and prevents the formation of adhesions and scars compared to the cell-free bioactive wound coverages [6].

The application of autologous cells to obtain skin equivalents prevents the possibility of immune rejection and the infection of a patient with foreign microorganisms, but it hinders obtaining of the product at the required moment and increases the cost of its production. Taking these two problems into consideration, the preference is given to the connective tissue cells, fibroblasts; this fact is confirmed by the communications about temporary immunogenic tolerance of the recipient organism to the allogeneic fibroblasts and their survival and proliferation in the donor organism for up to two months without the symptoms of the immune rejection $[7,8]$. At the same time the allogeneic keratinocytes are highly immunodominant, they are rejected by the organism and usually perish several weeks after the application onto the wound [9]. This earlier death, compared to the allogeneic fibroblasts, is likely to be the consequence of a high level of expression of human leukocyte antigen (HLA).

\section{Epidermal equivalents}

With the possibility of cultivating human keratinocytes in vitro and multiple increase in their total number [10], they were applied in the wound treatment [11], which promoted the survival of some serious

Table 1. The application of epidermal equivalents

\begin{tabular}{|c|c|c|}
\hline Brand & Producer, country & Objects for application \\
\hline Epicel & Genzyme Biosurgery, Cambridge, MA, USA & Massive burns [13] \\
\hline EPIBASE & Laboratoires Genevrier, Sophia-Antipolis, Nice, France & Massive burns [13] \\
\hline EpiDex & Modex Therapeutiques, Lausanne, Switzerland & Massive burns [13] \\
\hline MySkin & CellTran Ltd, Sheffield, UK & $\begin{array}{l}\text { Ulcers of lower extremities, superficial scalds; donor } \\
\text { sites for skin transplantat }[28,29]\end{array}$ \\
\hline $\begin{array}{l}\text { Laserskin } \\
\text { or Vivoderm }\end{array}$ & Fidia Advanced Biopolymers, Padua, Italy & $\begin{array}{l}\text { Preclinical animal tests }[30,31] \\
\text { Moderate clinical trials }[32]\end{array}$ \\
\hline Bioseed-S & BioTissue Technologies GmbH, Freiburg, Germany & $\begin{array}{l}\text { Chronic venous ulcers of lower extremities }[33,34] \\
\text { Full thickness wounds of animals }[22]\end{array}$ \\
\hline CellSpray & Clinical Cell Culture (C3), Perth, Australia & $\begin{array}{l}\text { Partial thickness wounds; donor sites for skin } \\
\text { transplantats [13] }\end{array}$ \\
\hline
\end{tabular}


patients [12]. The creation of epidermal equivalents involves the application of autologous keratinocytes, isolated from small $\left(2-5 \mathrm{~cm}^{2}\right)$ skin biopsy samples and proliferating in the culture with the formation of multilayer epithelial layers. These layers may be enzymatically separated from the surfaces of cultural vials and transferred to the supporting substrate, for instance, wax-bearing gauze or other carriers. This construction is applied to the wound taking into account basal-apical orientation of cells [13].

Using the modern methods of keratinocyte expansion in vitro, it is possible during 3-4 weeks to obtain from $3 \mathrm{~cm}^{2}$ of the tissue the epithelial autotransplantats, large enough to cover the whole body surface [14]. The drawbacks of such plate-like epithelial autotransplantats are long-term cultivation, fragility, complicated application of transplantats, and, mainly, unexpected clinical results in terms of different degree of acceptability -15 to $85 \%[13,15]$.

The enzymatic processing may change the structure of fibrils, responsible for the interaction of keratinocytes and the tissues of the recipient organism $[16,17]$. Due to this fact there is weak adhesion of the transplantat to the wound and the formation of blisters in case of even insignificant shifts months after the transplantation [11]. The cultivation of keratinocytes on special delivery membranes, which will be later applied to the wound surface along with the cultivated cells, allows avoiding the requirement of using enzymes $[16,18]$ and promotes the proliferation process, especially if natural, not synthetic, material is used. In particular, if fibrin is used as scaffold [18], the rate of transplantat formation increases almost three-fold.

At present epidermal equivalents are almost absent in the burn centers of Ukraine. Common drawbacks of these skin substitutes are the impossibility of their independent application in the therapy of full thickness wounds, only in the combination with dermal transplantats $[19,20]$ as well as their high cost.

Well-known epidermal equivalents Epicel [12], EPIBASE [21] and EpiDex [22], the earliest among similar bioconstructs, are mere sheets of keratinocytes, cultivated for 15 days. In addition to the abovementioned drawbacks, they have short (24 hours) shelf life [23]. Another commercial product, MySkin [24], consists of a scaffolding silicon membrane, covered with subconfluent layer of the cultivated keratinocytes. The keratinocytes of the product Laserskin (Vivoderm) [25] form a confluent layer on the surface of the hyaluronic micromeshed membrane and are capable of migrating downwards, through the scaffold, to the wound bed.

Products Bioseed-S [26] and CellSpray [27] involve the use of keratinocytes, composed of the subconfluent layer, in their most active proliferation state. The keratinocytes of the product of Bioseed-S company are evenly distributed inside the fibrin gel of allogeneic origin. Product CellSpray is merely the suspension of keratinocytes. After the application onto the wound surface the proliferation of keratinocytes continues up to the formation of the epithelial skin layer [14, 26, 27].

\section{Dermal equivalents}

Only a few of current dermal skin substitutes contain cells, since the production of large amounts of cell-free constructions is much easier and cheaper in large patches and it is much simpler to receive the license for their clinical application. It should be noted that dermal cellular coverages are almost unavailable for the application in burn centers of Ukraine.

As for well-known product TransCyte (previous name - Dermagraft-TC), the cultivated allogeneic fibroblasts are immobilized on the surface of the composite consisting of a silicon film, a nylon net and dermal porcine collagen. This temporary dermal coverage for the wound bed has to be removed after $7-14$ days and replaced by the autotransplantat. The scaffold of Dermagraft [35] consisting of polyglycolic acid, polylactic acid and extracellular matrix degrades on the wound surface via hydrolysis in 20 30 days. The extracelular matrix is produced by the cellular component, presented by cultivated allogeneic fibroblasts.

The bioconstruction Hyalograft 3D [36, 37] is formed by the hyaluronic micromeshed membrane, which is the scaffold for cultivated autologous fibroblasts. 


\section{Dermo-epidermal (composite) skin substitutes}

The dermo-epidermal equivalents contain cultivated fibroblasts and keratinocytes, located in different layers of the bioconstruction.

The bioengineered construction Apligraf (Apligraf Organogenesis Inc., USA) is currently the most successful clinical dermo-epidermal equivalent [9]. The cells of allogeneic origin form a confluent layer in the gel matrix of bovine type I collagen. The product is a temporary transplantat, resorbed on the wound surface, its drawback being short shelf life (up to 5 days).

The allogeneic fibroblasts of OrCell (OrCel Ortec International, Inc., USA) are immobilized inside the sponge-like gel of bovine type I collagen, one side of which has a formed confluent layer of allogeneic keratinocytes. The product is resorbed on the wound surface 7-14 days after the application.

The scaffolding porous matrix of PolyActive [44, 45] (PolyActive HC Implants BV, the Netherlands) consists of a soft component - poly(ethylene oxide) (PEO) - and a solid component - poly(butylene terephthalate) (PBT); it contains autologous cultivated cells. Notably, this bioconstruction is mainly used for bone reconstruction rather than for skin repair.

The Product TissueTech Autograft System (Fidia Advanced Biopolymers, Italy) [46]) is not a «pure» two-layer skin substitute, but rather the combination of dermis equivalent Hyalograft 3D and epidermis equivalent Laserskin.

\section{The search for novel bioengineered skin equivalents, containing cells}

\section{The elaboration of matrices using gelatin}

Gelatin, a natural product, is formed due to partial denaturation and degradation of collagen fibrils and like collagen is the attractant for fibroblasts in the wound healing processes $[49,50]$. Because of low cost and the possibility of in vivo degradation, gelatin is widely used as a coverage in wound treatment $[51,52,53]$. Other useful properties of gelatin are the absence of antigen activity, contrary to collagen [54], and strong hemostatic effect $[54,55]$. As gelatin is water-soluble, the molecules of gelatin-containing structures should be cross-linked for the application in long-living bioconstructions.

Table 2. The application of dermal equivalents

\begin{tabular}{|c|c|c|}
\hline Brand & Producer, country & Objects for application \\
\hline $\begin{array}{l}\text { TransCyte } \\
\text { (Dermagraft-TC) }\end{array}$ & $\begin{array}{l}\text { Advanced BioHealing, Inc., New York, } \\
\text { NY and La Jolla, CA, USA }\end{array}$ & $\begin{array}{l}\text { Burn wounds of partial thickness; donor sites of skin transplantats } \\
{[38,39,40] \text {. }}\end{array}$ \\
\hline Dermagraft & $\begin{array}{l}\text { Advanced BioHealing, Inc., New York, } \\
\text { NY and La Jolla, CA, USA }\end{array}$ & $\begin{array}{l}\text { Diabetic ulcers of lower extremities [41]. Venous ulcers [42]. Burn } \\
\text { wounds. }\end{array}$ \\
\hline Hyalograft 3D & $\begin{array}{l}\text { Fidia Advanced Biopolymers, Abano } \\
\text { Terme, Italy }\end{array}$ & $\begin{array}{l}\text { The stimulation of dermal-epidermal maturity [36, 37]. Ulcers of } \\
\text { lower extremities (in combination with Laserskin) [43]. }\end{array}$ \\
\hline
\end{tabular}

Table 3. The application of dermo-epidermal equivalents

\begin{tabular}{|l|l|l|}
\hline \multicolumn{1}{|c|}{ Brand } & \multicolumn{1}{|c|}{ Producer, country } & \multicolumn{1}{c|}{ Objects for application } \\
\hline Apligraf & $\begin{array}{l}\text { Organogenesis Inc., Canton, Massachusetts, } \\
\text { CA, USA } \\
\text { Ortec International, Inc., New York, NY, USA } \\
\text { OrCel }\end{array}$ & $\begin{array}{l}\text { Partial thickness burns [47, 48]. } \\
\text { Diabetic ulcers on legs [9]. } \\
\text { Burn wounds; donor sites for skin transplantats [6]. } \\
\text { PolyActive }\end{array}$ \\
$\begin{array}{l}\text { TissueTech } \\
\text { Autograft System } \\
\text { [44, 45]. } \\
\text { Ulcers of lower extremities. }\end{array}$ \\
\hline
\end{tabular}


Different types of biotechnological wound coverages created with the application of alive human cells

S. B. Lee et al. [56] described that the scaffold for human fibroblasts and keratinocytes was the surface of a porous matrix, consisting of gelatin and (1-3),(1$6)-\beta$-glucan. The latter is the carbohydrate of the microorganism Schizophyllum commune, which demonstrates the antibacterial, antiviral, anticoagulant and wound-healing activity [57].

Noteworthy is the work of H. M. Powell and S. T. Boyce [58] who used a fibrous matrix, formed by the electrospinning method. The composition of the construction included human fibroblasts and keratinocytes, forming confluent cellular layers between the fibrils. It should be noted that electrospinning is the high voltage process of creating long fibrils with the diameter ranging from nanometers to fractions of micrometer. Such e-spun fibrils are remarkable for high porosity and strong interrelation between the pores [59].

In contrast to the abovementioned works, Sh. Huang et al. [60] obtained so called gelatin microspheres of dozens to hundreds of micrometers, and viewed gelatin as a potential depot for the biologically active substances. Then the surfaces of microspheres were used to cultivate multipotent mesenchymal stromal cells (MMSC) of murine bone marrow, after which the microspheres were mixed with the solution of type I collagen. After gelatin jellying these bioconstructions were tested for treating burn wounds of mice with positive results.

Other authors, R. Quan et al. [61] used lyophilization while creating the cellular scaffold of the following composition - gelatin + chondroitin-6-sulfate + + hyaluronic acid. The stem cells of hair follicles, rarely used in similar research, served as a cellular component. The potential of these bioengineered products in the therapy of skin damage of laboratory rats was demonstrated.

R. V. Shevchenko et al. [62] used a bilayer cellular scaffold. The porous layer of gelatin contained human primary fibroblasts, and the silicon layer with smaller pores was cultivated with human keratinocytes. From the authors' standpoint, the results of the application of this dermal substitute in treating porcine skin damage allowed considering it as one of the biomedical constructions which will be used in future.

\section{The elaboration of matrices using collagen}

As shown by many authors, collagen is a good substrate for adhesion and proliferation of the cultivated cells. For instance, in the work of J. George et al. [63] the collagen porous matrix was applied on the layer of proliferating fibroblasts, which entered the pores and prolonged the proliferation for 60 days. As a result, the formed structure was morphologically similar to the dermal skin layer.

Different groups of researchers, for instance, A. Kinster et al. [64], S. H. Ahn et al. [65] also created porous collagen matrices. In these constructions fibroblasts were located inside the porous layer, whereas keratinocytes were on its surface, forming a well-developed multilayer epithelium [64] and even the external stratum corneum [65] similar to natural skin. A. El Ghalbzouri et al. [66] obtained the bioconstruction with a similar structure and cell distribution, but they created the matrix using human procollagen-I instead of commonly applied murine or bovine collagen.

In contrast to the abovementioned works, Kuikui Hu et al. [67] used as a scaffold the compressed collagen gel, obtained from the polymerized collagen with incorporated murine fibroblasts under pressure the compressed gel lost water and shrank while drying out, its mechanical properties were improved and the concentration of cells was increased. The murine keratinocytes formed a multilayer analogue of epidermis while being cultivated on the gel surface. The compression of collagen hydrogel, containing fibroblasts, was also used by C. Helary et al. [68]. The hydrogel became more stable and provided more effective proliferation of inside cells under favorable storage conditions.

The group of authors, H. M. Powell et al., used a sponge, made of collagen and chondroitin-6-sulfate, as a scaffold for human fibroblasts and keratinocytes [69]. In another work of the same group [70] a fibrous collagen matrix for cells was made by electrospinning. A similar fibrous scaffold for fibroblasts and keratinocytes was made by M. Kempf et al. [71] using bovine collagen-I.

The group of scientists from Great Britain and Taiwan $[72,73,74]$ synthesized a copolymer film using 
the combination of collagen and poly- $\varepsilon$-caprolactone (PCL) in 1:20 ratio. The latter is a biocompatible polymer [75], capable of enzymatic biodegradation [76]. At cultivation, one side of the film was covered with fibroblasts and other - with keratinocytes. J. Venugopal and S. Ramakrishna [77] obtained the copolymer nanofibrils using the combination of collagen and poly- $\varepsilon$-caprolactone via the electrospinning. Human fibroblasts were cultivated on the spun matrices. In [78] Ma et al. for the electrospinning of fibrils used collagen and polymer poly-(D,L)-lacticco-glycolic acid (PLGA), consisting of residues of lactic and glycolic acids at a ratio of 75:25, which is capable of biodegradation via hydrolysis. Human MMSC of bone marrow were used as a cellular component. As shown by the experiments on rats, the product obtained promoted the collagen synthesis and epithelium maturation in the wound bed.

M. Ananta et al. [79] used the combination of collagen with the same polymer; the latter was described as poly-(lactide-co-glycolide) (PLGA) and had commercial name Vicryl. The collagen layer with fibroblasts, evenly distributed within the volume, contained a PLGA net, which served as a frame to strengthen the construction. One of the surfaces of the collagen sheet carried keratinocytes. The cells were obtained using the skin of laboratory rabbits; further on the rabbits were used for the experiments, aimed at the study of the efficiency of applying this skin equivalent in burn therapy. The authors concluded that the bioconstructions obtained enhanced wound healing.

Noteworthy is the experimental work, in which P. Liu et al. [80] obtained MMSC out of bone marrow and cultivated them on the surface of the membrane, containing collagen and glycosaminoglycans. These bioconstructions were used in skin burn therapy. Yorkshire swines were used as laboratory animals to obtain MMSC and to simulate burns. The results were the improvement of wound vascularization, the stimulation of wound healing and the formation of epidermal skin layer.

In contrast to the abovementioned work, M. Keck et al. [81] cultivated human keratinocytes and preadipocytes on the previously constructed bioconstruction Matriderm ${ }^{\circledR}$, which was a sheet of bovine collagen, covered with dried hydrolysate of connective $\alpha$-elastin . Keratinocytes formed a confluent layer on the surface and preadipocytes penetrated into the samples.

Finally, R. K. Chan et al. [82] tried to create all three layers of skin coverages. The basis of the cellular component was adipose-derived stem cells (ASCs). The matrices for cellular masses were formed out of collagen, polyethylene glycol and fibrin. The incubation of separate constructions with cells in cultural media of different composition was used to achieve the transformation of ASCs into epithelial and adipose cells. During the creation of a dermal equivalent the cells did not undergo directed differentiation. The preclinical trials of the bioconstructions obtained are not described in the article, however, it can be understood («Further demonstration of this methodology in a preclinical model is under way») that to the moment of the article submission they have already been started.

The work of M. Itoh et al. [83] is noteworthy for the fact that they used human induced pluripotent stem cells (iPSC) as a source of cells. Previously these authors have informed about the possibility of artificial activation of iPSC differentiation into keratinocytes. In the mentioned work they developed a protocol of differentiating the same human iPSC into dermal fibroblasts. During the experiments they made samples of skin equivalents, containing the same cells, as those formed at the directed differentiation of iPSC. A collagen layer was applied on the surface of the polyethylene-terephthalate membrane, and after polymerization the fibroblasts and keratinocytes were cultivated consecutively, with the interval of 5-7 days. The authors did not conduct any preclinical trials of the bioconstructions obtained, but they informed that the histological structure was compatible with that of the equivalents, obtained using a similar method but with the application of normal human fibroblasts and keratinocytes.

\section{The elaboration of matrices using chitin/chitosan and other materials}

Chitin is a straight chain polysaccharide, whose monomer unit, $\mathrm{N}$-acetylglucosamine, is a part of hyaluronic acid, capable of stimulating dermis regenera- 
tion. Therefore chitin promotes the wound healing. Chitosan is a product of partial deacetylation of chitin and its separate monomer links. It should be noted that chitin and chitosan are biocompatible, i.e. they do not cause inflammatory or allergic reactions after local application or implantation into a human body [84], may be resorbed under the lysozyme action [85], and have bacteriostatic and fungistatic activity [86].

The example may be found in the work of G. M. Mykhailov et al. [87] who synthesized elastic chitin fibrils and wove a film of them. This film was later used to cultivate human fibroblasts, attached to the fibrils and flattened against them. A. B. Hilmi et al. [88] also used only two components - chitosan and primary fibroblasts of human origin, but the chitosan scaffold was made in the form of porous sheets, with the cells located inside them.

Two groups of researchers $[89,90]$ created a porous matrix using the mixture of collagen and chitosan solutions. The latter increases matrix biostability, which was demonstrated in the tests with collagenase [89] and lysozyme [90]. Human fibroblasts [90] or murine fibrosarcoma L929 cells [89] were used as a cellular component.

A noteworthy experimental work was conducted by I. N. Bolshakov et al. [91] who used as a cellular scaffold the collagen-chitosan complex, containing ascorbic, chondroitin-serine and hyaluronic acid, heparin and a medical preparation Adhelon (based on the bovine serum growth factor). They obtained films or porous sheets, on the surface of which the fetal murine fibroblasts were cultivated. The experiments with rats demonstrated that the application of these bioconstructions promotes complete restoration of the epidermal-dermal complex to the state, corresponding to that of healthy skin.

A. V. Yeremeyev et al. [92] observed good proliferative and metabolic activity of fetal murine fibroblasts and MMSC of adipose murine tissue while cultivating them on wound collagen-chitosan coverage Collakhit-bol (Patent of the Russian Federation N 2252787, 27.05.2005; Patent of the Russian Federation N 2254145, 20.06.2005). During cultivation the stromal cells started to differentiate into epithelial ones. J. Mao et al. [93] experimented with the cellular scaffold, consisting of chitosan and gelatin layers. Human fibroblasts and keratinocytes were used as a cellular component. The latter were introduced into the bioconstruction some time after the cultivation of fibroblasts on the matrix. Contrary to the abovementioned works, C. M. Han et al. [94] created a collagen-chitosan porous membrane. After a week-long cultivation its surface was covered with a fibrin layer, on which a layer of human keratinocytes was applied.

An original work was performed by Sh. Ikemoto et al. [95], where the authors succeeded in cultivating human keratinocytes on the membrane, consisting of chitosan, conjugated with protein AG73. This is one of representatives of the family of laminins over 30 large glycoproteins, located on the basal membrane. Among them, AG73 peptide is the most efficient stimulator of cell migration, adhesion and stimulation of axon germination. The authors deem their product to be a good vehicle to deliver keratinocytes to the wound bed.

Two groups of researchers $[96,97]$ used the electrospinning method to obtain cation nanofibrils using two components: chitosan, carrying short oligomer fragments of poly- $\varepsilon$-caprolactone (chitosan-graftpoly- $\varepsilon$-caprolactone), and pure poly- $\varepsilon$-caprolactone. The samples obtained demonstrated sufficient proliferation of murine fibrosarcoma L929 cells [96, 97], human osteosarcoma MG63 cells [97], fetal murine fibroblasts NIH3T3 [97].

\section{The elaboration of matrices using hyaluronic acid}

Hyaluronic acid is a polymer, consisting of the residues of D-glucuronic acid and D-N-acetylglucosamine, successively connected by $\beta-1,4$ - and $\beta-1,3$-glycosidic linkage. Natural molecules of hyaluronic acid may contain up to 25.000 disaccharide links. This substance, being one of the main components of a extracellular matrix, is a part of many biological fluids, participates in the processes of adhesion, migration and proliferation of fibroblasts and keratinocytes as well as in fetal non-scar wound healing [98].

Let us consider the series of experimental works involving the application of hyaluronic acid. T. W. Wang 
et al. [99] prepared a composite matrix via polymerization of the solution, containing gelatin, hyaluronic acid and chondroitin-6-sulfate in the concentrations of $5 \%, 0.2 \%$ and $0.05 \%$ respectively. H. Liu et al. $[100,101]$ synthesized the matrix using the solution of gelatin, chitosan acetate and hyaluronic acid in the concentrations of $0.7 \%, 0.4 \%$ and 0.001 $\%$ respectively. During the process of combined cultivation on the composite biopolymers the obtained human fibroblasts and keratinocytes demonstrated high viability and proliferation ability. The works $[100,101]$ showed that after two weeks keratinocytes gradually self-organized into a layer-like structure, which in particular included the layer of cubic cells and the surface layer of compressed cells. H. M. Wang et al. [102] also created a three-component matrix, consisting of collagen, hyaluronic acid and gelatin, whereas the cellular component included three types of cells instead of two: keratinocytes, melanocytes and fibroblasts. The skin equivalent obtained promoted wound healing in the in vivo experiments.

Noteworthy is the work, in which N. Scuderi et al. [103] described a clinical case of treating a surgical wound using the bioconstruction, based on the matrix of polymerized hyaluronic acid. The fibroblasts, keratinocytes and melanocytes, obtained during skin biopsy prior to the surgery, were jointly cultivated on this matrix. J. Enrione et al. [104] studied mechanical and physical properties of the same matrix and checked its cytotoxicity using cultivated human fibroblasts.

In the following work Sh. Kondo et al. [105] prepared composite porous matrices using hyaluronic acid, cross-linked collagen and epidermal growth factor (EGF). The latter considerably stimulated the fibroblasts proliferation on the matrix surface along with the formation of granular tissue in the wound, angiogenesis and epithelization of the wound in the experiments with rats.

\section{The elaboration of matrices using different synthetic polymers}

The film of the abovementioned poly- $\varepsilon$-caprolactone (PCL) was used in the work of K. W. Ng et al. [75] as a scaffold for human fibroblasts. Arun Richard
Chandrasekaran et al. [106] used the electrospinning method to create fibrils, containing poly-L-lacticacid-co-poly- $\varepsilon$-caprolactone and gelatin. Human fibroblasts served as a cellular component of the bioconstruction.

In the works of two groups, K. A. Blackwood et al. [107], S. G. Kumbar et al. [108], the combination of solutions of lactic and glycolic acids was used to elaborate copolymer fibrils of the poly(lactide-coglycolide) composition using the electrospinning method. This polymer has been mentioned above, but the authors of these works did not combine it with other materials. The fibrils obtained were used to spin biodegradable scaffolds for human fibroblasts and keratinocytes [107] or for human fibroblasts only [108]. In [107] the most efficient ratio of polylactic and polyglycolic acids was estimated to be $85: 15$ or $75: 25$.

\section{Other materials, used to elaborate matrices}

Complex matrices were made by A. L. Mazlyzam et al. [109]: for instance, they initiated the polymerization of human fibrin in the suspension of human fibroblasts. The abovementioned gel layer, carrying keratinocytes, was formed in a similar way. A layer of silk was applied for stabilization during the transportation and transplantation.

Human amniotic membrane was used as a cell scaffold in two works. S. S. Kim et al. [110] immobilized rabbit mesenchymal stromal cells (MSC) on its surface. In the work of Lujun Yang et al. [111] at first the membrane surface was covered with fibroblasts after the removal of the epithelial layer. Five days later, when the fibroblasts penetrated the membrane stroma, the surface was seeded with keratinocytes.

The remarkable work was performed by $\mathrm{C}$. Castagnoli et al. [112], in which the cell-free dermal layer of dead donor skin was used to create a skin equivalent. Then they cultivated keratinocytes on its surface for 21 days.

A work to be noted is the research of Chung Eun Yeum et al. [113] who cultivated MMSC, obtained from the bone marrow of laboratory mice, on the surface of small intestinal submucosa (SIS), one of the layers of intestinal walls, mechanically stable 
and formed by porous connective tissue. It was demonstrated that cells migrated from the surface of this scaffold into the wound bed, evolving growth factors. Here the number of cells, migrating to the wound surface, reached some maximal value (depending on the wound size) and further on remained constant, even if the number of MMSC, brought to the wound bed in the composition of transplantats, was increased.

\section{Our studies on the basis of Human Genetics Department of IMBG NAS of Ukraine.}

Since 2001 we have conducted biotechnological research in developing dermal skin equivalents, containing living human cells. Human multipotent mesenchymal stromal cells (MMSC) of different origin were studied as a cellular component. Primary skin cells and the cells of 4BL line were used [114]. Currently MMSC, obtained from human placenta, became a new source of cells $[115,116]$. The works in obtaining dermal skin equivalents using MMSC are being conducted in the collaboration with the Cell Therapy Institute, Kyiv, which has a license (AG 579626) for the elaboration and maintenance of low temperature bank of human cells and tissues.

Different materials of synthetic and natural origin are used as a scaffold. Previously there have been some experiments with hydrogel membranes, synthesized in the F. D. Ovcharenko Institute of Biocolloid Chemistry NASU (Kyiv) using combined polymerization of acrylamide and acrylonitrile [117, 118]. There have been joint clinical studies of different dermal coverages on the limited number of patients with massive and deep burns in the collaboration with the Center of Thermal Injuries and Plastic Surgery of the Kyiv City Hospital No. 2. The samples of hydrogels, based on the synthetic polyacrylamide matrix and natural collagen matrix with immobilized MMSC, were applied on the wounds, previously cleansed from necrotic tissues. Twenty-four hours later the temporary dermal coverages were removed with the subsequent autotransplantation of skin. In the control cases the autotransplantation of skin was conducted without previous application of hydrogel dermal coverages on wounds. It was demonstrated that both synthetic and natural biomatrix/ cell constructions were non-toxic, solid, elastic, transparent or semitransparent, with good fixation on the wound and partial adsorption of excessive tissue exudate, and convenient in the application. The use of temporary skin substitutes made subsequent fixation of meshed autotransplantats more reliable, accelerated their transfer to the vascular type of nutrition and increased the rate of epithelization of meshed spaces almost twice. The positive results of clinical trials allowed receiving two patents of Ukraine Patent of Ukraine (N 20134, 15.01.2007; Patent of Ukraine N 82583, 10.01.2008), the third patent is currently being considered.

\section{Conclusion}

At the current stage of biotechnology development the available epidermal, dermal and dermo-epidermal skin equivalents are not capable of replacing skin tissue completely. Usually they serve as a temporary biologically active coverage, providing the damaged part of skin with cytokines, growth factors and other biologically active substances, which promotes wound healing due to the stimulation of regeneration of the patient's own tissues. Therefore, the skin substitutes play a incomplete, yet relevant role in the complex treatment of the deep and/or extensive skin damage, facilitating the survival of patients and improving the quality of their life after the trauma. Further studies in this field are rather urgent for the elaboration of new cellular technologies in biology and medicine.

\section{REFERENCES}

1. Pruitt BA, Levine NS. Characteristics and uses of biologic dressings and skin substitutes. Arch Surg. 1984;119(3):312-22.

2. Lacroix M, Bovy T, Nusgens BV, Lapière CM. Keratinocytes modulate the biosynthetic phenotype of dermal fibroblasts at a pretranslational level in a human skin equivalent. Arch Dermatol Res. 1995;287(7):659-64.

3. Archambault M, Yaar M, Gilchrest BA. Keratinocytes and fibroblasts in a human skin equivalent model enhance melanocyte survival and melanin synthesis after ultraviolet irradiation. J Invest Dermatol. 1995;104(5):859-67.

4. Eaglstein $W H$, Falanga $V$. Tissue engineering for skin: an update. J Am Acad Dermatol. 1998;39(6):1007-10. 
5. Ehrenreich M, Ruszczak Z. Update on tissue-engineered biological dressings. Tissue Eng. 2006;12(9):2407-24.

6. Still J, Glat P, Silverstein P, Griswold J, Mozingo D. The use of a collagen sponge/living cell composite material to treat donor sites in burn patients. Burns. 2003;29(8):837-41.

7. Hebda PA, Dohar JE. Transplanted fetal fibroblasts: survival and distribution over time in normal adult dermis compared with autogenic, allogenic, and xenogenic adult fibroblasts. Otolaryngol Head Neck Surg. 1999;121(3):245-51.

8. Sandulache VC, Zhou Z, Sherman A, Dohar JE, Hebda PA. Impact of transplanted fibroblasts on rabbit skin wounds. Arch Otolaryngol Head Neck Surg. 2003;129(3):345-50.

9. Clark RA, Ghosh K, Tonnesen MG. Tissue engineering for cutaneous wounds. J Invest Dermatol. 2007;127(5):1018-29.

10. Rheinwald JG, Green $H$. Serial cultivation of strains of human epidermal keratinocytes: the formation of keratinizing colonies from single cells. Cell. 1975;6(3):331-43.

11. Gallico GG, O’Connor NE, Compton CC, Kehinde O, Green $H$. Permanent coverage of large burn wounds with autologous cultured human epithelium. N Engl J Med. 1984;311 (7): 448-51.

12. Carsin H, Ainaud P, Le Bever H, Rives J, Lakhel A, Stephanazzi J, Lambert F, Perrot J. Cultured epithelial autografts in extensive burn coverage of severely traumatized patients: a five year single-center experience with 30 patients. Burns. 2000;26(4):379-87.

13. Atiyeh BS, Costagliola M. Cultured epithelial autograft (CEA) in burn treatment: three decades later. Burns. 2007;33(4): 405-13.

14. Chester DL, Balderson DS, Papini RP. A review of keratinocyte delivery to the wound bed. J Burn Care Rehabil. 2004;25(3):266-75.

15. Williamson JS, Snelling CF, Clugston P, Macdonald IB, Germann E. Cultured epithelial autograft: five years of clinical experience with twenty-eight patients. J Trauma. 1995; 39(2):309-19.

16. Hernon CA, Dawson RA, Freedlander E, Short R, Haddow DB, Brotherston M, MacNeil S. Clinical experience using cultured epithelial autografts leads to an alternative methodology for transferring skin cells from the laboratory to the patient. Regen Med. 2006;1(6):809-21.

17. Compton CC, Gill JM, Bradford DA, Regauer S, Gallico GG, O'Connor NE. Skin regenerated from cultured epithelial autografts on full-thickness burn wounds from 6 days to 5 years after grafting. A light, electron microscopic and immunohistochemical study. Lab Invest. 1989;60(5):600-12.

18. Ronfard V, Rives JM, Neveux Y, Carsin H, Barrandon $Y$. Long-term regeneration of human epidermis on third degree burns transplanted with autologous cultured epithelium grown on a fibrin matrix. Transplantation. 2000;70(11): 1588-98.

19. Wood FM, Kolybaba ML, Allen P. The use of cultured epithelial autograft in the treatment of major burn injuries: a critical review of the literature. Burns. 2006;32(4):395-401.
20. Wood FM, Kolybaba ML, Allen P. The use of cultured epithelial autograft in the treatment of major burn wounds: eleven years of clinical experience. Burns. 2006;32(5):538-44.

21. Vacher $D$. [Autologous epidermal sheets production for skin cellular therapy]. Ann Pharm Fr. 2003;61(3):203-6.

22. Tausche AK, Skaria M, Böhlen L, Liebold K, Hafner J, Friedlein H, Meurer M, Goedkoop RJ, Wollina U, Salomon D, Hunziker T. An autologous epidermal equivalent tissueengineered from follicular outer root sheath keratinocytes is as effective as split-thickness skin autograft in recalcitrant vascular leg ulcers. Wound Repair Regen. 2003;11(4): 248-52.

23. Horch RE, Kopp J, Kneser U, Beier J, Bach AD. Tissue engineering of cultured skin substitutes. J Cell Mol Med. 2005; 9(3):592-608.

24. Moustafa M, Simpson C, Glover M, Dawson RA, Tesfaye S, Creagh FM, Haddow D, Short R, Heller S, MacNeil S. A new autologous keratinocyte dressing treatment for non-healing diabetic neuropathic foot ulcers. Diabet Med. 2004;21(7): 786-9.

25. Ramos-e-Silva M, Ribeiro de Castro MC. New dressings, including tissue-engineered living skin. Clin Dermatol. 2002; 20(6):715-23.

26. Grant I, Warwick K, Marshall J, Green C, Martin R. The coapplication of sprayed cultured autologous keratinocytes and autologous fibrin sealant in a porcine wound model. $\mathrm{Br}$ J Plast Surg. 2002;55(3):219-27.

27. Navarro FA, Stoner ML, Park CS, Huertas JC, Lee HB, Wood FM, Orgill DP. Sprayed keratinocyte suspensions accelerate epidermal coverage in a porcine microwound model. J Burn Care Rehabil. 2000;21(6):513-8.

28. Zhu N, Warner RM, Simpson C, Glover M, Hernon CA, Kelly J, Fraser S, Brotherston TM, Ralston DR, MacNeil S. Treatment of burns and chronic wounds using a new cell transfer dressing for delivery of autologous keratinocytes. Eur $J$ Plast Surg. 2005;28(5):319-30

29. Moustafa M, Bullock AJ, Creagh FM, Heller S, Jeffcoate W, Game F, Amery C, Tesfaye S, Ince Z, Haddow DB, MacNeil $S$. Randomized, controlled, single-blind study on use of autologous keratinocytes on a transfer dressing to treat nonhealing diabetic ulcers. Regen Med. 2007;2(6):887-902.

30. Lam PK, Chan ES, To EW, Lau CH, Yen SC, King WW. Development and evaluation of a new composite Laserskin graft. J Trauma. 1999;47(5):918-22.

31. Myers SR, Partha VN, Soranzo C, Price RD, Navsaria HA. Hyalomatrix: a temporary epidermal barrier, hyaluronan delivery, and neodermis induction system for keratinocyte stem cell therapy. Tissue Eng. 2007;13(11):2733-41.

32. Price RD, Das-Gupta V, Leigh IM, Navsaria HA. A comparison of tissue-engineered hyaluronic acid dermal matrices in a human wound model. Tissue Eng. 2006;12(10):2985-95.

33. Johnsen $S$, Ermuth T, Tanczos E, Bannasch H, Horch RE, Zschocke I, Peschen M, Schöpf E, Vanscheidt W, Augustin M. Treatment of therapy-refractive ulcera cruris of various ori- 
Different types of biotechnological wound coverages created with the application of alive human cells

gins with autologous keratinocytes in fibrin sealant. Vasa. 2005;34(1):25-9.

34. Vanscheidt W, Ukat A, Horak V, Brüning H, Hunyadi J, Pavlicek R, Emter M, Hartmann A, Bende J, Zwingers T, Ermuth $T$, Eberhardt $R$. Treatment of recalcitrant venous leg ulcers with autologous keratinocytes in fibrin sealant: a multinational randomized controlled clinical trial. Wound Repair Regen. 2007;15(3):308-15.

35. Kim PJ, Dybowski KS, Steinberg JS. A closer look at bioengineered alternative tissues. Podiatry Today. 2006;19(7).

36. Stark HJ, Willhauck MJ, Mirancea N, Boehnke K, Nord I, Breitkreutz D, Pavesio A, Boukamp P, Fusenig NE. Authentic fibroblast matrix in dermal equivalents normalises epidermal histogenesis and dermoepidermal junction in organotypic co-culture. Eur J Cell Biol. 2004;83(11-12):631-45.

37. Stark HJ, Boehnke K, Mirancea N, Willhauck MJ, Pavesio A, Fusenig NE, Boukamp P. Epidermal homeostasis in longterm scaffold-enforced skin equivalents. J Investig Dermatol Symp Proc. 2006;11(1):93-105.

38. Demling $R H$. Use of Biobrane in management of scalds. $J$ Burn Care Rehabil. 1995;16(3 Pt 1):329-30.

39. Barret JP, Dziewulski P, Ramzy PI, Wolf SE, Desai MH, Herndon DN. Biobrane versus $1 \%$ silver sulfadiazine in second-degree pediatric burns. Plast Reconstr Surg. 2000;105 (1):62-5.

40. Pape SA, Byrne PO. Safety and efficacy of TransCyte for the treatment of partial-thickness burns. J Burn Care Rehabil. 2000;21(4):390.

41. Marston WA, Hanft J, Norwood P, Pollak R; Dermagraft Diabetic Foot Ulcer Study Group. The efficacy and safety of Dermagraft in improving the healing of chronic diabetic foot ulcers: results of a prospective randomized trial. Diabetes Care. 2003;26(6):1701-5.

42. Omar AA, Mavor AI, Jones AM, Homer-Vanniasinkam S. Treatment of venous leg ulcers with Dermagraft. Eur J VasC Endovasc Surg. 2004;27(6):666-72.

43. Caravaggi $C$, De Giglio $R$, Pritelli C, Sommaria $M$, Dalla Noce S, Faglia E, Mantero M, Clerici G, Fratino P, Dalla Paola L, Mariani G, Mingardi R, Morabito A. HYAFF 11based autologous dermal and epidermal grafts in the treatment of noninfected diabetic plantar and dorsal foot ulcers: a prospective, multicenter, controlled, randomized clinical trial. Diabetes Care. 2003;26(10):2853-9.

44. Xiao YL, Riesle J, Van Blitterswijk CA. Static and dynamic fibroblast seeding and cultivation in porous PEO/PBT scaffolds. J Mater Sci Mater Med. 1999;10(12):773-7.

45. El-Ghalbzouri A, Lamme EN, van Blitterswijk C, Koopman J, Ponec $M$. The use of PEGT/PBT as a dermal scaffold for skin tissue engineering. Biomaterials. 2004;25(15):2987-96.

46. Uccioli L; TissueTech Autograph System Italian Study Group. A clinical investigation on the characteristics and outcomes of treating chronic lower extremity wounds using the tissuetech autograft system. Int J Low Extrem Wounds. 2003; 2(3):140-51.
47. Waymack $P$, Duff RG, Sabolinski $M$. The effect of a tissue engineered bilayered living skin analog, over meshed splitthickness autografts on the healing of excised burn wounds. The Apligraf Burn Study Group. Burns. 2000;26(7):609-19.

48. Hayes DW, Webb GE, Mandracchia VJ, John KJ. Full-thickness burn of the foot: successful treatment with Apligraf. A case report. Clin Podiatr Med Surg. 2001;18(1):179-88.

49. Meier S, Hay ED. Control of corneal differentiation by extracellular materials. Collagen as a promoter and stabilizer of epithelial stroma production. Dev Biol. 1974;38(2): 249-70.

50. Gey GO, Svotelis M, Foard M, Bang FB. Long-term growth of chicken fibroblasts on a collagen substrate. Exp Cell Res. 1974;84(1):63-71.

51. Neumann PM, Zur B, Ehrenreich Y. Gelatin-based sprayable foam as a skin substitute. J Biomed Mater Res. 1981;15 (1):9-18.

52. Lee SB, Kim YH, Chong MS, Hong SH, Lee YM. Study of gelatin-containing artificial skin $\mathrm{V}$ : fabrication of gelatin scaffolds using a salt-leaching method. Biomaterials. 2005;26 (14):1961-8.

53. Zhang YZ, Venugopal J, Huang Z.-M, Lim CT, Ramakrishna $S$. Crosslinking of the electrospun gelatin nanofibers. Polymer. 2006; 47(8): 2911-7.

54. Tomihata K, Burczak K, Shiraki K, Ikada Y. Cross-Linking and Biodegradation of Native and Denatured Collagen In: Polymers of biological and biomedical importance. Eds: Shalaby SW, Ikada Y, Langer RS, Williams J, American Chemical Society Symposium Series. - Washington, DC: American Chemical Society, 1994. 540: 275-86.

55. Rose PI. Gelatin. In: Encyclopedia of polymer science and engineering Eds: Mark HF, Bikales NM, Overberger CG, Menges G, Kroschwitz J--New York: Wiley; 1987;7, 2nd ed. 488-513.

56. Lee SB, Jeon HW, Lee YW, Lee YM, Song KW, Park MH, Nam YS, Ahn HC. Bio-artificial skin composed of gelatin and (1-->3), (1-->6)-beta-glucan. Biomaterials. 2003;24(14): 2503-11.

57. Bohn JA, BeMiller JN. (1-3)- $\beta$-D-Glucans as biological response modifiers: a review of structure-functional activity relationships. Carbohydr Polym. 1995; 28(1): 3-14.

58. Powell HM, Boyce ST. Fiber density of electrospun gelatin scaffolds regulates morphogenesis of dermal-epidermal skin substitutes. J Biomed Mater Res A. 2008;84(4):1078-86.

59. Park JS. Electrospinning and its applications. Adv Nat Sci: Nanosci Nanotechnol. 2010;1(4):043002.

60. Huang $S, L u G, W u$ Y, Jirigala E, Xu Y, Ma K, Fu X. Mesenchymal stem cells delivered in a microsphere-based engineered skin contribute to cutaneous wound healing and sweat gland repair. J Dermatol Sci. 2012;66(1):29-36.

61. Quan R, Zheng X, Xu S, Zhang L, Yang D. Gelatin-chondroitin-6-sulfate-hyaluronic acid scaffold seeded with vascular endothelial growth factor 165 modified hair follicle stem cells as a three-dimensional skin substitute. Stem Cell Res Ther. 2014;5(5):118. 
62. Shevchenko RV, Eeman M, Rowshanravan B, Allan IU, Savina IN, Illsley $M$, Salmon M, James SL, Mikhalovsky SV, James SE. The in vitro characterization of a gelatin scaffold, prepared by cryogelation and assessed in vivo as a dermal replacement in wound repair. Acta Biomater. 2014; 10(7):3156-66.

63. George J, Onodera J, Miyata T. Biodegradable honeycomb collagen scaffold for dermal tissue engineering. $J$ Biomed Mater Res A. 2008;87(4):1103-11.

64. Kinsner A, Lesiak-Cyganowska E, Sladowski D. In vitro reconstruction of full thickness human skin on a composite collagen material. Cell Tissue Bank. 2001;2(3):165-71.

65. Ahn S, Yoon H, Kim G, Kim Y, Lee S, Chun W. Designed three-dimensional collagen scaffolds for skin tissue regeneration. Tissue Eng Part C Methods. 2010;16(5):813-20.

66. El Ghalbzouri A, Commandeur S, Rietveld MH, Mulder AA, Willemze R. Replacement of animal-derived collagen matrix by human fibroblast-derived dermal matrix for human skin equivalent products. Biomaterials. 2009;30(1):71-8.

67. Hu K, Shi H, Zhu J, Deng D, Zhou G, Zhang W, Cao Y, Liu $W$. Compressed collagen gel as the scaffold for skin engineering. Biomed Microdevices. 2010;12(4):627-35.

68. Helary C, Zarka M, Giraud-Guille MM. Fibroblasts within concentrated collagen hydrogels favour chronic skin wound healing. J Tissue Eng Regen Med. 2012;6(3):225-37.

69. Powell HM, Boyce ST. Wound closure with EDC cross-linked cultured skin substitutes grafted to athymic mice. Biomaterials. 2007;28(6):1084-92.

70. Powell HM, Supp DM, Boyce ST. Influence of electrospun collagen on wound contraction of engineered skin substitutes. Biomaterials. 2008;29(7):834-43.

71. Kempf M, Miyamura Y, Liu PY, Chen AC, Nakamura $H$, Shimizu H, Tabata Y, Kimble RM, McMillan JR. A denatured collagen microfiber scaffold seeded with human fibroblasts and keratinocytes for skin grafting. Biomaterials. 2011;32(21):4782-92.

72. Dai NT, Williamson MR, Khammo N, Adams EF, Coombes AG. Composite cell support membranes based on collagen and polycaprolactone for tissue engineering of skin. Biomaterials. 2004;25(18):4263-71.

73. Dai NT, Yeh MK, Liu DD, Adams EF, Chiang CH, Yen CY, Shih CM, Sytwu HK, Chen TM, Wang HJ, Williamson MR, Coombes AG. A co-cultured skin model based on cell support membranes. Biochem Biophys Res Commun. 2005;329 (3): 905-8.

74. Dai NT, Yeh MK, Chiang CH, Chen KC, Liu TH, Feng AC, Chao LL, Shih CM, Sytwu HK, Chen SL, Chen TM, Adams EF. Human single-donor composite skin substitutes based on collagen and polycaprolactone copolymer. Biochem Biophys Res Commun. 2009;386(1):21-5.

75. Ng KW, Hutmacher DW, Schantz JT, Ng CS, Too HP, Lim TC, Phan TT, Teoh SH. Evaluation of ultra-thin poly(epsilon-caprolactone) films for tissue-engineered skin. Tissue Eng. 2001;7(4):441-55.
76. Pitt CG, Chasalow FI, Hibionada YM, Kilmas DM, Schindler A. Aliphatic polyesters. 1 . The degradation of poly ( $\varepsilon$-caprolactone) in vivo. J Appl Polym Sci. 1981; 26(11): 3779-87.

77. Venugopal J, Ramakrishna S. Biocompatible nanofiber matrices for the engineering of a dermal substitute for skin regeneration. Tissue Eng. 2005;11(5-6):847-54.

78. Ma K, Liao S, He L, Lu J, Ramakrishna S, Chan CK. Effects of nanofiber/stem cell composite on wound healing in acute full-thickness skin wounds. Tissue Eng Part A. 2011;17(910):1413-24.

79. Ananta $M$, Brown RA, Mudera $V$. A rapid fabricated living dermal equivalent for skin tissue engineering: an in vivo evaluation in an acute wound model. Tissue Eng Part A. 2012; 18(3-4):353-61.

80. Liu P, Deng Z, Han S, Liu T, Wen N, Lu W, Geng X, Huang S, Jin $Y$. Tissue-engineered skin containing mesenchymal stem cells improves burn wounds. Artif Organs. 2008;32(12): 925-31.

81. Keck M, Haluza D, Lumenta DB, Burjak S, Eisenbock B, Kamolz LP, Frey M. Construction of a multi-layer skin substitute: Simultaneous cultivation of keratinocytes and preadipocytes on a dermal template. Burns. 2011;37(4):626-30.

82. Chan RK, Zamora DO, Wrice NL, Baer DG, Renz EM, Christy RJ, Natesan S. Development of a vascularized skin construct using adipose-derived stem cells from debrided burned skin. Stem Cells Int. 2012;2012:841203.

83. Itoh M, Umegaki-Arao N, Guo Z, Liu L, Higgins CA, Christiano $A M$. Generation of $3 \mathrm{D}$ skin equivalents fully reconstituted from human induced pluripotent stem cells (iPSCs). PLoS One. 2013;8(10):e77673.

84. Pianigiani E, Andreassi A, Taddeucci P, Alessandrini C, Fimiani $M$, Andreassi $L$. A new model for studying differentiation and growth of epidermal cultures on hyaluronanbased carrier. Biomaterials. 1999;20(18):1689-94.

85. Domard A, Rinaudo $M$. Preparation and characterization of fully deacetylated chitosan. Int J Biol Macromol. 1983;5(1): 49-52.

86. Tomihata K, Ikada Y. In vitro and in vivo degradation of films of chitin and its deacetylated derivatives. Biomaterials. 1997;18(7):567-75.

87. Mikhailov GM, Lebedeva MF, Pinaev GP, Iudintseva NM, Blinova MI, Panarin EF. New woven matrix made of resorbed natural chitin polysaccaride for culturing and transplantation of human skin cells. Cell Transplantation and Tissue Engineering. 2006; 4(6):56-61.

88. Hilmi AB, Halim AS, Hassan A, Lim CK, Noorsal K, Zainol I. In vitro characterization of a chitosan skin regenerating template as a scaffold for cells cultivation. Springerplus. 2013;2(1):79.

89. Ma L, Gao C, Mao Z, Zhou J, Shen J, Hu X, Han C. Collagen/ chitosan porous scaffolds with improved biostability for skin tissue engineering. Biomaterials. 2003;24(26):4833-41.

90. Tangsadthakun C, Kanokpanont S, Sanchavanakit N, Banaprasert T, Damrongsakkul S. Properties of collagen/chitosan 
Different types of biotechnological wound coverages created with the application of alive human cells

scaffolds for skin tissue engineering. Journal of Metals, Materials and Minerals. 2006: 16(1):37-44.

91. Bolshakov IN, Kirichenko AK, Eremeev AV, Vlasov AA. Application of a collagen-chitosan wound covering with cultured embryonic fibroblasts in the local treatment of deep burns. Fundamental research. 2008;(10):59.

92. Eremeev AV, Svetlakov AV, Bolshakov IN, Vlasov AA, Arapova VA. Function of cultivating embryonic cells on collagen-chitosan matrix. Cell Transplantation and Tissue Engineering. 2009; IV(2):55-62.

93. Mao J, Zhao L, De Yao K, Shang Q, Yang G, Cao Y. Study of novel chitosan-gelatin artificial skin in vitro. $J$ Biomed Mater Res A. 2003;64(2):301-8.

94. Han CM, Zhang LP, Sun JZ, Shi HF, Zhou J, Gao CY. Application of collagen-chitosan/fibrin glue asymmetric scaffolds in skin tissue engineering. J Zhejiang Univ Sci B. 2010; 11(7):524-30.

95. Ikemoto S, Mochizuki M, Yamada M, Takeda A, Uchinuma E, Yamashina S, Nomizu M, Kadoya Y. Laminin peptide-conjugated chitosan membrane: Application for keratinocyte delivery in wounded skin. J Biomed Mater Res A. 2006;79 (3):716-22.

96. Chen H, Huang J, Yu J, Liu S, Gu P. Electrospun chitosangraft-poly ( $\varepsilon$-caprolactone)/poly ( $\varepsilon$-caprolactone) cationic nanofibrous mats as potential scaffolds for skin tissue engineering. Int J Biol Macromol. 2011;48(1):13-9

97. Shalumon KT, Anulekha KH, Chennazhi KP, Tamura $H$, Nair SV, Jayakumar R. Fabrication of chitosan/poly (caprolactone) nanofibrous scaffold for bone and skin tissue engineering. Int J Biol Macromol. 2011;48(4):571-6

98. Price RD, Berry MG, Navsaria HA. Hyaluronic acid: the scientific and clinical evidence. J Plast Reconstr Aesthet Surg. 2007;60(10):1110-9.

99. Wang TW, Sun JS, Wu HC, Tsuang YH, Wang WH, Lin FH. The effect of gelatin-chondroitin sulfate-hyaluronic acid skin substitute on wound healing in SCID mice. Biomaterials. 2006;27(33):5689-97.

100. Liu H, Mao J, Yao K, Yang G, Cui L, Cao Y. A study on a chitosan-gelatin-hyaluronic acid scaffold as artificial skin in vitro and its tissue engineering applications. J Biomater Sci Polym Ed. 2004;15(1):25-40.

101. Liu H, Yin Y, Yao K. Construction of chitosan-gelatin-hyaluronic acid artificial skin in vitro. J Biomater Appl. 2007; 21(4):413-30.

102. Wang HM, Chou YT, Wen ZH, Wang CZ, Chen CH, Ho ML. Novel biodegradable porous scaffold applied to skin regeneration. PLoS One. 2013;8(6):e56330.

103. Scuderi N, Onesti MG, Bistoni G, Ceccarelli S, Rotolo S, Angeloni A, Marchese $C$. The clinical application of autologous bioengineered skin based on a hyaluronic acid scaffold. Biomaterials. 2008;29(11):1620-9.

104. Enrione J, Osorio F, Lopez D, Weinstein-Oppenheimer C, Fuentes MA, Ceriani R, Brown DI, Albornoz F, Sanchez E, Villalobos $P$, Somoza RA, Young ME, Acevedo CA. Charac- terization of a Gelatin/Chitosan/Hyaluronan scaffold-polymer. Electron J Biotechnol. 2010; 13(5).

105. Kondo S, Kuroyanagi Y. Development of a wound dressing composed of hyaluronic acid and collagen sponge with epidermal growth factor. J Biomater Sci Polym Ed. 2012;23(5): 629-43.

106. Chandrasekaran AR, Venugopal J, Sundarrajan S, Ramakrishna S. Fabrication of a nanofibrous scaffold with improved bioactivity for culture of human dermal fibroblasts for skin regeneration. Biomed Mater. 2011;6(1):015001.

107. Blackwood KA, McKean R, Canton I, Freeman CO, Franklin KL, Cole D, Brook I, Farthing P, Rimmer S, Haycock JW, Ryan AJ, MacNeil S. Development of biodegradable electrospun scaffolds for dermal replacement. Biomaterials. 2008;29(21):3091-104.

108. Kumbar SG, Nukavarapu SP, James R, Nair LS, Laurencin CT. Electrospun poly(lactic acid-co-glycolic acid) scaffolds for skin tissue engineering. Biomaterials. 2008;29(30): 4100-7.

109. Mazlyzam AL, Aminuddin BS, Fuzina NH, Norhayati MM, Fauziah O, Isa MR, Saim L, Ruszymah BH. Reconstruction of living bilayer human skin equivalent utilizing human fibrin as a scaffold. Burns. 2007;33(3):355-63.

110. Kim SS, Song CK, Shon SK, Lee KY, Kim CH, Lee MJ, Wang L. Effects of human amniotic membrane grafts combined with marrow mesenchymal stem cells on healing of full-thickness skin defects in rabbits. Cell Tissue Res. 2009; 336(1):59-66.

111. Yang L, Shirakata Y, Tokumaru S, Xiuju D, Tohyama M, Hanakawa Y, Hirakawa S, Sayama K, Hashimoto K. Living skin equivalents constructed using human amnions as a matrix. J Dermatol Sci. 2009;56(3):188-95.

112. Castagnoli C, Fumagalli M, Alotto D, Cambieri I, Casarin S, Ostorero A, Casimiri R, Germano P, Pezzuto C, Stella M. Preparation and characterization of a novel skin substitute. $J$ Biomed Biotechnol. 2010;2010. pii: 840363

113. Yeum CE, Park EY, Lee SB, Chun HJ, Chae GT. Quantification of MSCs involved in wound healing: use of SIS to transfer MSCs to wound site and quantification of MSCs involved in skin wound healing. J Tissue Eng Regen Med. 2013;7(4):279-91.

114. Lukash LL, Iatsishina AP, Kushniruk VO, Pidpala OV. Reprogramming of adult somatic human cells in vitro. Factors of experimental evolution. Kyiv: Logos, 2011; 11: 493-8.

115. Shablii VA., Kuchma MD, Kyryk VM, Onishchenko AN, Lukash LL, Lobitseva GS. Cryopreservation human placental tissue as source of hematopoietic and mesenchymal stem cells. Cell Transplantation and Tissue Engineering. 2012. VII(1):54-62.

116. Shablii V, Kuchma M, Kyryk V, Onishchenko G, Areshkov P, Skrypnyk N, Lukash L, Lobyntseva G. Characteristics of placental multipotent mesenchymal stromal stem cells. Cell Transplantation and Tissue Engineering. 2013; VIII(4): 55-61. 
117. Kosenko OO, Lukash LL, Samchenko UM, Ruban TA, Ulberg ZR, Lukash SI. Copolymeric hydrogel membranes for immobilization and cultivation of human stem cells. Biopolym Cell. 2006;22(2):143-8.

118. Kosenko OO, Lukash LL, Samchenko YuM, Ruban TA, Lukash SI, Ulberg ZR, Galagan NP. Artificial skin equivalent based on copolymeric hydrogel membranes with immobilized human mesenchymal stem cells. Biopolym Cell. 2006; 22(6):446-51.

\section{Різні типи біотехнологічних ранових покриттів, створених 3 використанням живих клітин людини}

О. Є. Папуга, Л. Л. Лукаш

В нинішній час залишається надзвичайно актуальною розробка та впровадження в клінічну практику нових біотехнологічних ранових покриттів (еквівалентів шкіри), покликаних тимчасово або постійно замінювати пошкоджені або зруйновані ділянки шкіри людини. Серед штучних ранових покриттів особливе місце займають еквіваленти шкіри або іiі окремих шарів, що містять у своєму складі живі клітини різних типів та походження. До складу біоконструкцій найчастіше входять два основних типи клітин - фібробласти і кератиноцити (спільно або окремо). Такі біоконструкцій служать, зазвичай, як тимчасові покриття, що забезпечують пошкоджену шкіру біологічно активними речовинами і стимулюють регенерацію власних тканин пацієнта. У нашому огляді розглядаються як комерційно доступні раневі покриття, так і такі, які ще досліджуються в лабораторіях. Донині ще не створено ідеальних замінників шкіри, тому зусилля багатьох дослідників спрямовані на вирішення цього завдання.
Кл юч о в і с с о в а: штучна шкіра, еквіваленти або замінники шкіри, ранові дермальні покриття, тканинна інженерія, клітина, опікова рана.

Различные типы биотехнологических раневых покрытий, созданных с использованием живых клеток человека

А. Е. Папуга, Л. Л. Лукаш

В настоящее время остаётся чрезвычайно актуальной разработка и внедрение в клиническую практику новых биотехнологических раневых покрытий (эквивалентов кожи), призванных временно или постоянно заменять повреждённые или разрушенные участки кожи человека. Среди искусственных раневых покрытий особое место занимают эквиваленты кожи или её отдельных слоёв, имеющие в своём составе живые клетки различных типов и происхождения. В состав биоконструкций чаще всего входят два основных типа клеток - фибробласты и кератиноциты (совместно или отдельно). Такие биоконструкции служат, как правило, в качестве временных покрытий, которые снабжают поврежденную кожу биологически активными веществами и стимулируют регенерацию собственных тканей пациента. В нашем обзоре рассматриваются как коммерчески доступные раневые покрытия, так и те, которые ещё исследуются в лабораториях. До настоящего времени ещё не созданы идеальные заменители кожи, поэтому усилия многих исследователей направлены на решение этой задачи.

К л юч е в ы е с л о в а: искусственная кожа, эквиваленты или заменители кожи, раневые дермальные покрытия, тканевая инженерия, клетка, ожоговая рана.

Received 10.01.2014 